\title{
IMPACT OF MINING ACTIVITIES IN THE UPPER SILESIAN COAL BASIN ON SURFACE WATER AND POSSIBILITIES OF ITS REDUCTION
}

\author{
Andrzej Harat ${ }^{1}$, Nada Rapantova², Arnost Grmela², Zdzisław Adamczyk ${ }^{3}$ \\ 1 University of Bielsko-Biala, Willowa Str. 2, 43-309 Bielsko-Biała, Poland, e-mail: aharat@ath.bielsko.pl \\ 2 VŠB Technical University of Ostrava, Faculty of Mining and Geology, Institute of Geological Engineering, Str. \\ 17. listopadu 15/2172, Ostrava-Poruba, Czech Republic, e-mail: nada.rapantova@vsb.cz; arnost.grmela@vsb.cz \\ 3 Silesian University of Technology, Institute of Applied Geology, Akademicka Str. 2, 44-101 Gliwice, Poland, \\ e-mail: zdzislaw.adamczyk@polsl.pl
}

Received: 2015.05 .16

Accepted: 2015.06.02

Published: 2015.07.01

\begin{abstract}
Due to the deposits of quality hard coal, the area of the Upper Silesian Coal Basin (USCB) has been one of the most industrialised regions in Europe for centuries. One of the most significant issues in terms of environmental impact and risks related to mining activities are the discharged mine waters. Mine water is pumped to the surface in great amount from mine workings of active underground mines both in Czech and Polish part of the USCB. In the past, the mine waters used to be discharged to nearby watercourses without systematic control of their amount and quality. It resulted in uncontrolled impacts on quality of the main rivers in the USCB. This is why a technically and economically demanding solution was adopted: discharging of mine (but also waste) waters through an artificial channel - so-called "Olza Collector" - directly to the Oder River, i.e. away of the Olza River and its minor tributaries. Automated control and dosing of waters to the Oder River depending on quality of the discharged waters and quality and quantity of the Oder surface water ensures maintaining of the total content of chlorides and sulphates in Oder below $500 \mathrm{mg} / \mathrm{dm}^{3}$ with the efficiency of more than $90 \%$ of days in a year.
\end{abstract}

Keywords: mine water, Upper Silesian Coal Basin (USCB), Olza Collector.

\section{INTRODUCTION}

Due to the deposits of quality hard coal, the area of the Upper Silesian Coal Basin (USCB) has been one of the most industrialised regions in Europe for centuries. Apart from coal, tin and lead ores there are deep-mined and sands and gravel opencast-mined in the Polish part of the Upper Silesian Basin [Różkowski et al. 2007]. One of the most significant issues in terms of environmental impact and risks related to mining activities mine waters are discharged but there are also uncontrolled water overflows to surface from previously abandoned mines after the mining is terminated. Mine waters are pumped to the surface in great amount from mine workings of active underground mines both in Czech and Pol- ish part of the USCB. The waters are subsequently discharged to surface watercourses whose waters then exceed the generally valid limits of acceptable pollution according to the Water Act (especially in the parameters of total mineralization (Total Dissolved Solids - TDS) by chloride and sulphate ions). This situation needs to be settled by defining exceptions which e.g. in the case of the border profile on the Odra River in Bohumín amount to: total dissolved solids TDS $=\max .1000 \mathrm{mg} / \mathrm{dm}^{3} ; \mathrm{SO}_{4}{ }^{2-}=\max .200 \mathrm{mg} / \mathrm{dm}^{3}$; $\mathrm{Cl}^{-}$: Odra flow $<10 \mathrm{~m}^{3} / \mathrm{s}=350 \mathrm{mg} / \mathrm{dm}^{3}$, Odra discharge $<10-16 \mathrm{~m}^{3} / \mathrm{s}=300 \mathrm{mg} / \mathrm{dm}^{3}$, Odra flow $>16 \mathrm{~m}^{3} / \mathrm{s}=250 \mathrm{mg} / \mathrm{dm}^{3} ; \mathrm{Fe}=\max .5 \mathrm{mg} / \mathrm{dm}^{3}$.

Negative impact of discharging mine waters to surface watercourses on water quality in them is documented by the results of systematic 
monitoring carried out within monitoring of environment quality in the Polish as well as in the Czech part of the Basin. An example illustrating scope of the problem can be the data contained in a report of the Regional Inspectorate for Environmental Protection in Katowice (WIOŚ) stating that 117.3 mil. $\mathrm{m}^{3}$ of mine waters with total content of 1.3 tons of chlorides and sulphates were discharged in Silesian Voivodeship in 2013 [Wrześniak 2013]. The main contamination load affects border reach of the Olza River and subsequently the Odra River.

When adopting and applying the required measures to eliminate negative impact of the discharged mineralised mine waters on the environment, their quality and specifics of local conditions shall be taken into account. The area of the USCB is highly populated and apart from that - from the hydrologic point of view - it is located in the divide of two main Polish rivers, Vistula and Odra, which is characterised by rather small reserves of groundwater resources. Due to the long-term and intensive mining activities, these reserves need to be considered highly degenerated in terms of quality and quantity. Negative impacts of mining activities manifest themselves in this area by flooded depressions caused by subsidences in the undermined areas and by the newly formed networks of channels and drainage ditches.

This article brings information about practical solution of the issue of quality protection of the main watercourses in areas of deep mining within the boundaries of Czech and Polish parts of the USCB, i.e. mainly protection of quality of the border Olza River. Principle of the solution is based on transferring mine waters from smaller drainage surface courses with low rate of flow (Leśnica, Szotkówka but also Olza) to the artificially created channel, so-called "Olza Collector" taking the waters directly to the Odra River. Apart from the mine waters discharged from active mines in Polish part of the USCB, discharging of waste waters from residential buildings, septic tanks, water treatment plants etc. is connected to this collector. The Olza Collector is a $70 \mathrm{~km}$ long water mains equipped with a computer-controlled final dosing of waste water to the Odra River according to the defined limits. This way general conditions of environmental protection are fulfilled in each municipality for the local watercourse as well as the duties implied by the international agreement concluded on $11^{\text {th }}$ April 1996 (and valid from $28^{\text {th }}$ April 1999) among Po- land, the Czech Republic, Federal Republic of Germany and the International Commission of the Protection of the Odra River against Pollution with the aim to prevent and continuously decrease the pollutant load on Odra and the Baltic Sea. The long-term monitoring of quality of Olza and Odra surface waters is an excellent example of fruitful cooperation between neighbouring countries in environmental monitoring.

\section{MINING ACTIVITIES IN THE UPPER SILESIAN COAL BASIN}

In Czech part of the Upper Silesian Basin, the end of the $18^{\text {th }}$ century is considered the beginning of coal mining. The highest annual output was achieved in 1970's (approx. 24 mil. tons of coal). Current level of annual output ranges between 8.5 and 10 mil. tons.

After the WWII, the Czech part of the USCB, so-called Ostrava-Karviná District, was divided into four partial basins:

1) Ostrava partial basin (in the west) - mining activities were terminated,

2) Petřvald partial basin (central part) - mining activities were terminated,

3) Karviná partial basin (in the east) - in exploitation (OKD, a.s. - Mine 1 and 2),

4) Lower Beskids basin: Př́ibor-Těšín partial ba$\sin (\mathrm{OKD}$, a.s. - Mine 3 /previously the Paskov Mine), Frenštát partial basin - the Frenštát Mine without mining activities.

In the Ostrava partial basin, mining was terminated in 1995. Mine waters from a part of the flooded mines are kept by pumping on the level of $-385 \mathrm{~m}$ below sea level in the Jeremenko Water Shaft. Pumped waters are discharged to the Ostravice River (subsequently with an overflow to the Odra in Ostrava Muglinov) in the amount of 160 1/s [Harat and Grmela 2008].

In the Petřvald partial basin, mining was terminated in 2000. Mine waters from a part of the flooded mines are kept by pumping on the level of $-480 \mathrm{~m}$ below sea level in the Žofie Water Shaft. Pumped waters are discharged to the Stružka watercourse (subsequently with an overflow to Odra in Bohumín-Vrbice) in the amount of 37 1/s [Schwalbová 2009].

At present, mining in the Czech part of the USCB only takes place in eastern part of the basin, i.e. in the Karviná partial basin, and mine waters are discharged to the Karvinský Stream 
(Mine 1) and to the Stonávka Stream (Mine 2) - both with a subsequent overflow to Olza. Western part of the working district of today's Mine 1 (area of the previous Lazy Mine) is drained by the Stružka Stream and subsequently to the Odra River in Bohumín-Vrbice.

Some of the oldest mines in the Polish part of the USCB are the Murcki Mine opened in 1740, the Reden Mine (1785) or the Siemianowice Mine (1788). Present annual output in the Polish part of the USCB amounts to approx. 75 mil. tons. The largest mines in this part of the USCB are the Borynia, Budryk, Jastrzębie-Moszczenica, Krupiński, Pniówek and Zofiówka Mines. Mining areas in the South of the Polish part of the USCB and in Czech parts of this coal basin are shown in Figure 1. As visible in the picture, the focus of today's mining is in the Polish part of the USCB (the coal mines belong to "Jastrzębska Spółka Węglowa, S.A." and "Kompania Węglowa, S.A." - previously "Rybnická uhelná společnost)".

One of the largest tributaries of Olza (in southern part of the USCB) affected by the discharged mine waters is Szotkówka to which Leśnica, Ruptawka and Jastrzebianka empty; the tributary of Odra is mainly the Ruda River and tributary of the Vistula catchment area is the Pszczynka River (see Fig. 2). Considerable amount of polluted municipal and industrial waste waters from the towns of Wodzisław Śląski and Jastrzębie [Rusin 2007] is also taken to the Szotkówky River. Contamination load on the Olza flow has been eliminated by the construction of the Olza Collector since 2004; with the Collector emptied directly to the Odra River with sufficiently high flow rate, the quality of water in the Olza River improved.

\section{EFFECT OF MINING ACTIVITIES ON WATER POLLUTIONS IN THE USCB}

An important factor affecting conditions of the hydrosphere in the USCB is mainly the mining activity. Deep mining of coal is connected not only to the formation of subsidence depressions, their flooding, slope deformations, landslides, structure destructions etc. but also to disruption of the original rock massif above the stopes of the coal seams in a form of joints or faults. From the hydrogeological point of view, these deformations create new drainage pathways for groundwaters from the originally closed aquiferous systems and allow overflows of groundwaters on the surface or vice versa - through these drainage ways, they allow surface waters to infiltrate to the rock environment or even to mine workings. All waters which penetrate to mine workings (whether from natural aquifers or from the surface, or technological water etc.) form so called mine waters in the rock environment. Mine waters are usu-

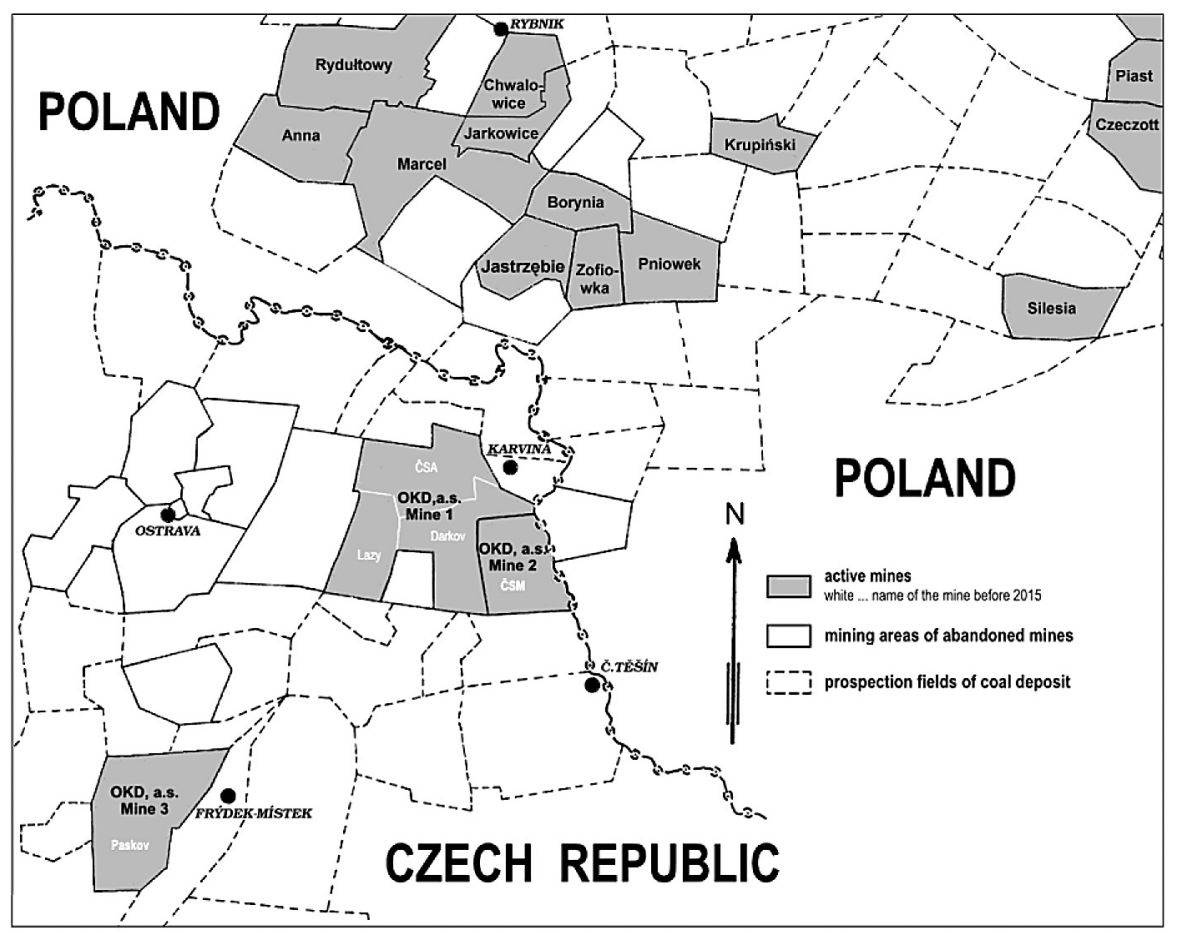

Figure 1. Areas of mining exploitation in Polish and Czech parts of the Upper Silesian Coal Basin [Dopita et al. 1997, modified] 
ally pumped to the surface and eliminated by discharging to surface watercourses. The discharged mine waters are usually mildly to strongly mineralised (see below) and generally mentioned as "saline waters".

Water recharging to mine workings through the rock environment causes mixing of waters as well as hydrochemical reactions between rock minerals and water. The resulting chemical composition of mine waters is significantly influenced by the mine atmosphere which aggressively affects both the rock environment (weathering creation of new easily soluble minerals ) and the water environment (precipitation of salts or their re-dissolving etc.). A typical effect of water and atmosphere in mining environment of coal deposits is e.g. oxidation of sulphide minerals (e.g. pyrite, marcasite) with mine water beneficiated enriched by sulphates and iron. Specific sources of mine water pollution are also the anthropogenic materials used in mine workings (ashes, various construction materials, technological solutions, oils and lubricants, wastes related to coal transportation etc.). Mine waters are therefore mixed waters of various origin and composition, waters that result from the interaction with rock environment and mine atmosphere. According to Pluta [Pluta 2005], the sources of mine waters can be specified as:

- Sources of geogenic waters (natural waters flowing to mine workings from the rock environment, including their interaction with natural environment),

- Sources of anthropogenic contamination (mine environment - backfill material, supports of mine workings, biogenic contamination etc.),

- Sources connected to technological processes related to mining (technologic waters, lubricants, fire-extinguishing materials, oil products etc.).

Watercourses in the areas, which are currently highly affected by mining activities (but also strongly urbanized and industrialised) - such as the surroundings of Karviná in the Czech Republic or the area of Rybnik in Poland (i.e. Rybnicki Okręg Węglowy /ROW/) - are loaded with saline mine waters. It mainly relates to the Olza River or its tributaries Stonávka, Karvinský Stream, Szotkówka and Leśnica. Emptying of these creaks is the cause of sudden significant changes in chemism of Olza surface waters which impact the original fauna and flora. In the case of Leśnica, the plants and animals have been completely devastated [Pluta 2005, Swolkień 2007].

Subsequently the quality of water in the Odra River, a river of the $1^{\text {st }}$ order, is affected though less seriously due to its higher water discharge.

Mine waters taken from active coal mines to surface watercourses are a contamination load for the quality of river waters, especially due to their high total mineralisation (TDS), high concentrations of chlorides and sodium (the reason of saline taste of these waters), concentration of sulphates and generally the suspended solids (Table 1). Apart from these main components, mine waters contain increased concentrations of ammonium ions and ions of potassium, calcium, magnesium and iron As a consequence of the chemical processes of mixing the sources of mine waters and their interaction with the mine and rock environ-

Table 1. Major ions and elements and their concentrations in groundwaters of the USCB [Pluta 2005, Wilk et al. 2003 - modified]

\begin{tabular}{|c|c|c|}
\hline Name & \multicolumn{2}{|c|}{ Content $\left[\mathrm{mg} / \mathrm{dm}^{3}\right]$} \\
\hline \multirow{10}{*}{ Main cations } & $\mathrm{Ca}^{2+}$ & $2.4-10900$ \\
\hline & $\mathrm{Mg}^{2+}$ & $0.1-7300$ \\
\hline & $\mathrm{Na}^{+}$ & $1.9-103000$ \\
\hline & $\mathrm{K}^{+}$ & $0.4-10000$ \\
\hline & $\mathrm{Fe}^{2+, 3+}($ total $)$ & $0.01-300$ \\
\hline & $\mathrm{NH}_{4}^{+}$ & $0.003-100$ \\
\hline & $\mathrm{Ba}^{2+}$ & $<830$ \\
\hline & $\mathrm{Sr}^{2+}$ & $<50$ \\
\hline & $\mathrm{B}^{3+}$ & $<3.50$ \\
\hline & $\mathrm{Li}^{+}$ & $<40$ \\
\hline \multirow{7}{*}{ Main anions } & $\mathrm{HCO}_{3}^{-}$ & $4.5-2800$ \\
\hline & $\mathrm{SO}_{4}^{2-}$ & $<640$ \\
\hline & $\mathrm{Cl}^{-}$ & $0.1-187900$ \\
\hline & $\mathrm{N}-\mathrm{NO}_{3}^{-}$ & $<40$ \\
\hline & 1 & $<130$ \\
\hline & $\mathrm{Br}$ & $<290$ \\
\hline & $\mathrm{PO}_{4}^{3-}$ & $<10$ \\
\hline \multirow{8}{*}{ Heavy metals } & $\mathrm{Cr}^{2+}$ & $0.05-1$ \\
\hline & $\mathrm{Cu}^{2+}$ & $0.15-0.3$ \\
\hline & $\mathrm{Ni}^{2+}$ & $0.3-1.5$ \\
\hline & $\mathrm{Cd}^{2+}$ & $0.15-0.75$ \\
\hline & $\mathrm{Pb}^{2+}$ & $0.01-1.6$ \\
\hline & $\mathrm{Co}^{2+}$ & $<0.8$ \\
\hline & $\mathrm{Zn}^{2+}$ & $0.15-1.00$ \\
\hline & $\mathrm{Mn}^{2+}$ & $<6$ \\
\hline $\begin{array}{l}\text { Radioactive } \\
\text { elements }\end{array}$ & ${ }^{226} \mathrm{Ra}$ & $<96 \mathrm{~Bq} / \mathrm{dm}^{3}$ \\
\hline
\end{tabular}


ment, including hydrolysis, the waters are also enriched with heavy metal ions. In case of high content of barium in mine waters, white precipitates of barium sulphate etc. appear in sediments of watercourses and water reservoirs.

Apart from the variable chemical composition, mine waters are also typical by various level of total mineralisation (TDS). In the case of the USCB, mine waters according to TDS are qualified as follows [Wilk et al. 2003]:

- fresh - TDS smaller than $1 \mathrm{~g} / \mathrm{dm}^{3}$ (basic types $\mathrm{Ca}-\mathrm{HCO}_{3}, \mathrm{Ca}-\mathrm{HCO}_{3} \mathrm{SO}_{4}, \mathrm{Ca}-\mathrm{Mg}-\mathrm{SO}_{4-} \mathrm{HCO}_{3}$ and $\mathrm{Na}-\mathrm{Cl}-\mathrm{HCO}_{3)}$,

- mildly mineralised - TDS 1 to $3 \mathrm{~g} / \mathrm{dm}^{3}$, (basic types of water similar to the previous ones),

- medium mineralised - TDS 3 to $10 \mathrm{~g} / \mathrm{dm}^{3}$ (basic types $\mathrm{Na}-\mathrm{Cl}, \mathrm{Na}-\mathrm{Cl}-\mathrm{HCO}_{3}$ and $\mathrm{Ca}-\mathrm{Mg}-\mathrm{SO}_{4}$. $\mathrm{HCO}_{3}$ ) - waters mainly from the oxidation zone,

- strongly mineralised - TDS 10 to $35 \mathrm{~g} / \mathrm{dm}^{3}$ (basic type $\mathrm{Na}-\mathrm{Cl}$ ) - waters in oxidation as well as reduction zone,

- brines - TDS more than $35 \mathrm{~g} / \mathrm{dm}^{3}$ (basic types of water $\mathrm{Na}-\mathrm{Ca}-\mathrm{Cl}, \mathrm{Na}-\mathrm{Cl}$ ) - waters in the reduction zone.

Different classification of mine waters in the USCB focused on their potential use is provided by Pluta [Pluta and Grmela 2006]:

- fresh - TDS smaller than $1 \mathrm{~g} / \mathrm{dm}^{3}$; content of $\mathrm{Cl}^{-}$and $\mathrm{SO}_{4}{ }^{2-}$ smaller than $0.6 \mathrm{~g} / \mathrm{dm}^{3}$; waters in this group can be used as non-potable water, in exceptional cases even as potable water,
- industrial - TDS 1 to $3 \mathrm{~g} / \mathrm{dm}^{3}$, content of $\mathrm{Cl}^{-}$ and $\mathrm{SO}_{4}{ }^{2-}$ between 0.6 and $1.8 \mathrm{~g} / \mathrm{dm}^{3}$; waters in this group can be used in industry - after or without treatment,

- mildly mineralised - TDS 3 to $70 \mathrm{~g} / \mathrm{dm}^{3}$, content of $\mathrm{Cl}^{-}$and $\mathrm{SO}_{4}{ }^{2-}$ between 1.8 to $70 \mathrm{~g} / \mathrm{dm}^{3}$; waters in this group have low utilization in the industry; their elimination is both economic and environmental load for the environment (they cause increased salinity of surface waters),

- brines - TDS more than $70 \mathrm{~g} / \mathrm{dm}^{3}$, content of $\mathrm{Cl}^{-}$and $\mathrm{SO}_{4}{ }^{2-}$ higher than $42 \mathrm{~g} / \mathrm{dm}^{3}$; waters in this group are a very high load for surface watercourses and shallow groundwaters. They can be used in balneology or in production of bath salts, in exceptional cases as process water.

In the past, the mine waters used to be discharged to nearby watercourses without systematic control of their quantity and quality. It resulted in uncontrolled impacts on quality of the main rivers in the USCB. The waters became absolutely unsuitable for the use in households and even in the industry. Figure 2 shows the values of mineralisation in watercourses in southern part of the Polish USCB in this period. It documents the very negative impact of mining activities on quality of surface waters especially in the catchment area of the border Olza River which resulted in adopting protective measures for water quality in this part of the USCB. The project was called "The Olza Collector" and was based on an

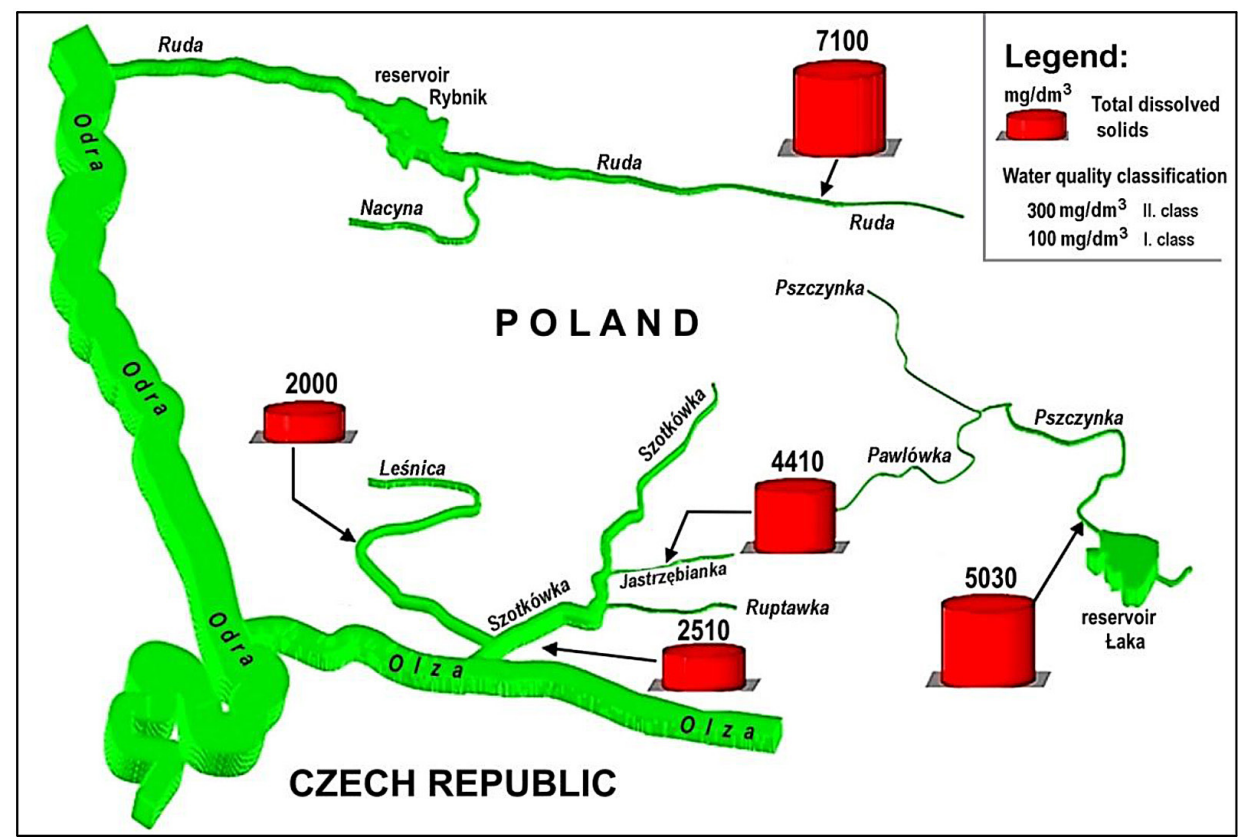

Figure 2. Salinity condition of USCB's major rivers $\left[\mathrm{mg} / \mathrm{dm}^{3}\right]$ without control of the mine water discharge [Swolkień 2007 - modified] 
artificial drainpipe ("collector") taking the saline mine waters from Polish mines in the right-bank catchment area of Olza directly to the Odra River. At that time, the high load of surface waters in the Olza catchment area - mainly by chlorides and sulphates from mine waters - achieved the level corresponding with degradation of their biological recovery. The system of mine drainage in Czech part of the Basin has not changed by this measure.

\section{THE OLZA COLLECTOR}

Construction of the "Olza Collector" started in 1971 and continued until 1986 all the way to the town of Turza Śląska $10 \mathrm{~km}$ before the planned emptying to the Odra River (see Figure 3). In this point, waters from the Collector were temporarily discharged to Leśnica in the amount of approx. $30000 \mathrm{~m}^{3} /$ day and then through Olza to Odra [Lach 2003]. This accepted temporary solution which lasted for 11 years had a very negative impact on the ecosystem of the Leśnica watercourse and subsequently also on Olza due to their low water discharge. Final works commenced in 1997 and terminated on $20^{\text {th }}$ December 2003; full operation of the Olza Collector (after the $8 \mathrm{~km}$ long section of pipe mains was completed) started on $12^{\text {th }}$ March 2004.

System of the Olza Collector is administered by Przedsiębiorstwo Gospodarki Wodnej i Rekultywacji S.A. (PGWiR). The Collector in
Table 2. List of mines in the "Olza Collector" system

\begin{tabular}{|c|c|}
\hline \multicolumn{2}{|c|}{ Coal mines } \\
\hline $\begin{array}{c}\text { Jastrzębska Spółka Węglowa S.A } \\
\text { "Borynia” (including the abandoned } \\
\text { mine „KWK Żory”) }\end{array}$ & $\begin{array}{c}\text { Kompania Węglowa } \\
\text { S.A. }\end{array}$ \\
\hline $\begin{array}{c}\text { "Jas-Mos" (including the abandoned” } \\
\text { mine „KWK Moszczenica”) }\end{array}$ & "Chwałowice” \\
\hline „Krupiński” & "Jankowice” \\
\hline „Pniówek” & \\
\hline „Zofiówka" & \\
\hline
\end{tabular}

the overall length of $73 \mathrm{~km}$ conducts mine waters from the mines of Jastrzębska Spółka Węglowa S.A. and Kompania Węglowa S.A. (see Table 2 and Figure 3). Apart from mine waters of the above mines, the system of Olza Collector drains also the waters from residential buildings of miners' settlements, pumping stations, reservoirs etc. by means of the piping network (profile of the steel/polyethylene pipes varies between 300 and $800 \mathrm{~mm}$ ) interconnecting the mines.

The present operation and administration of the "Olza Collector" is fully automated and computer-controlled (special "Olza-dyspozytor" software) with the aim to optimize pumping and final discharging of waste waters from the Olza Collector to Odra according to current flow rate in the river and the water quality. Decree of the polish Ministry of Environment of $24^{\text {th }}$ July 2006, on discharging of waste waters to watercourses or surface waters, does not directly define conditions for mine waters discharged by the Olza Collector

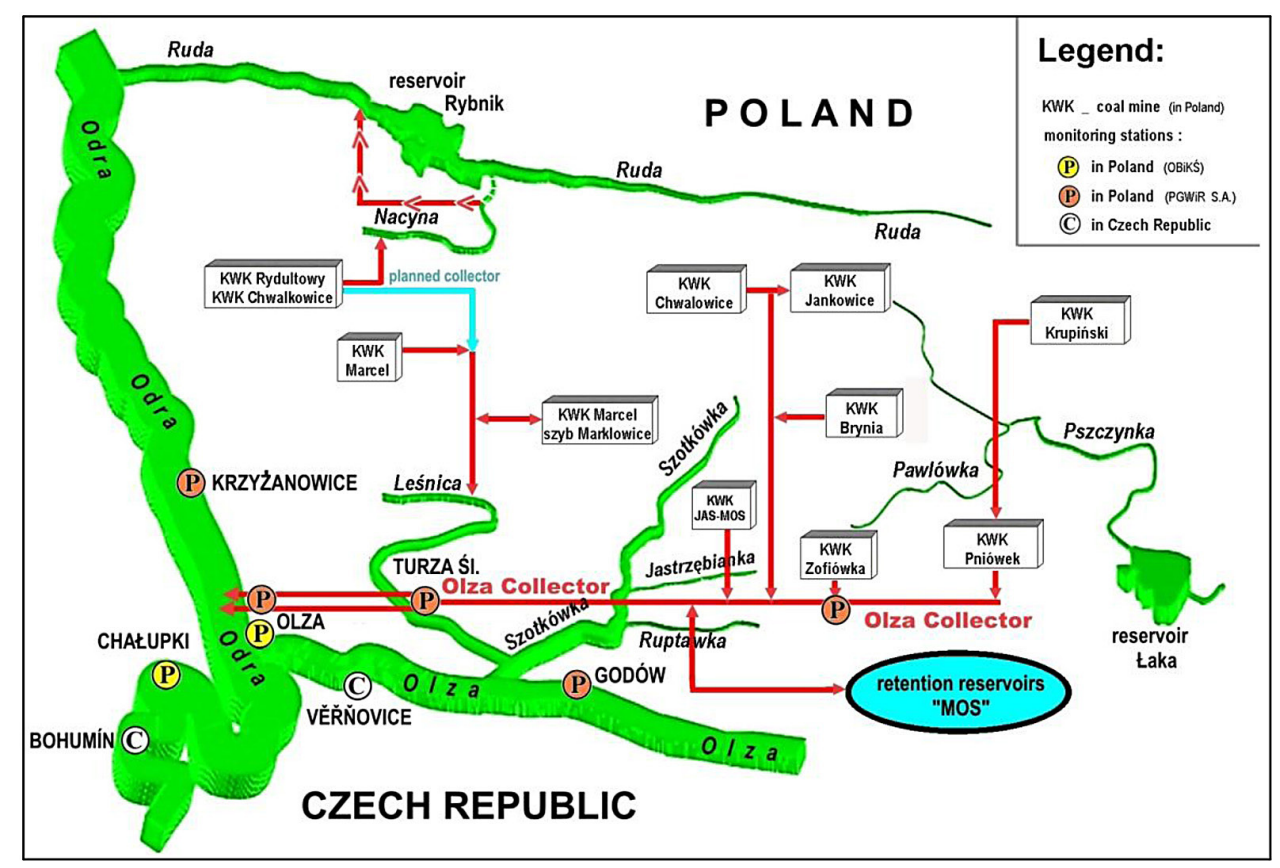

Figure 3. Scheme of the "Olza Collector" [Walaszek 2013 - modified] 
or for the content of substances especially harmful to the environment. The following conditions were adopted for the Olza Collector - dosing of waste waters from the collector to the Odra River shall be kept at such a level that the total content of chlorides and sulphates does not exceed the value of $500 \mathrm{mg} / \mathrm{dm}^{3}$ for at least on 300 days in a year, i.e. approx. in $90 \%$ of a year. It should be highlighted that the limit level of $500 \mathrm{mg} / \mathrm{dm}^{3}$ is given by internal regulation of the Collector administrator PGWiR S.A. Legal limits for total mineralisation (TDS) of surface watercourses in Poland amounts to $1000 \mathrm{mg} / \mathrm{dm}^{3}$. The fact that the Olza Collector administrator defined a value at lower than the legal limit for TDS is based on company's strategy to save natural sources and quality of surface waters in international watercourses but mainly on the effort to keep sufficient buffer in quality of the Odra water for discharging of other mine waters in central and northern part of the Polish part of the USCB.

The graphs (Figures 4, 5 and 6) show the development of chloride and sulphate concentration in Odra before and after emptying of the Olza Collector.

\section{CONCLUSION}

Quality and quantity of water in rivers draining deposit area of the Upper Silesian Coal Basin both in Poland and in the Czech Republic are

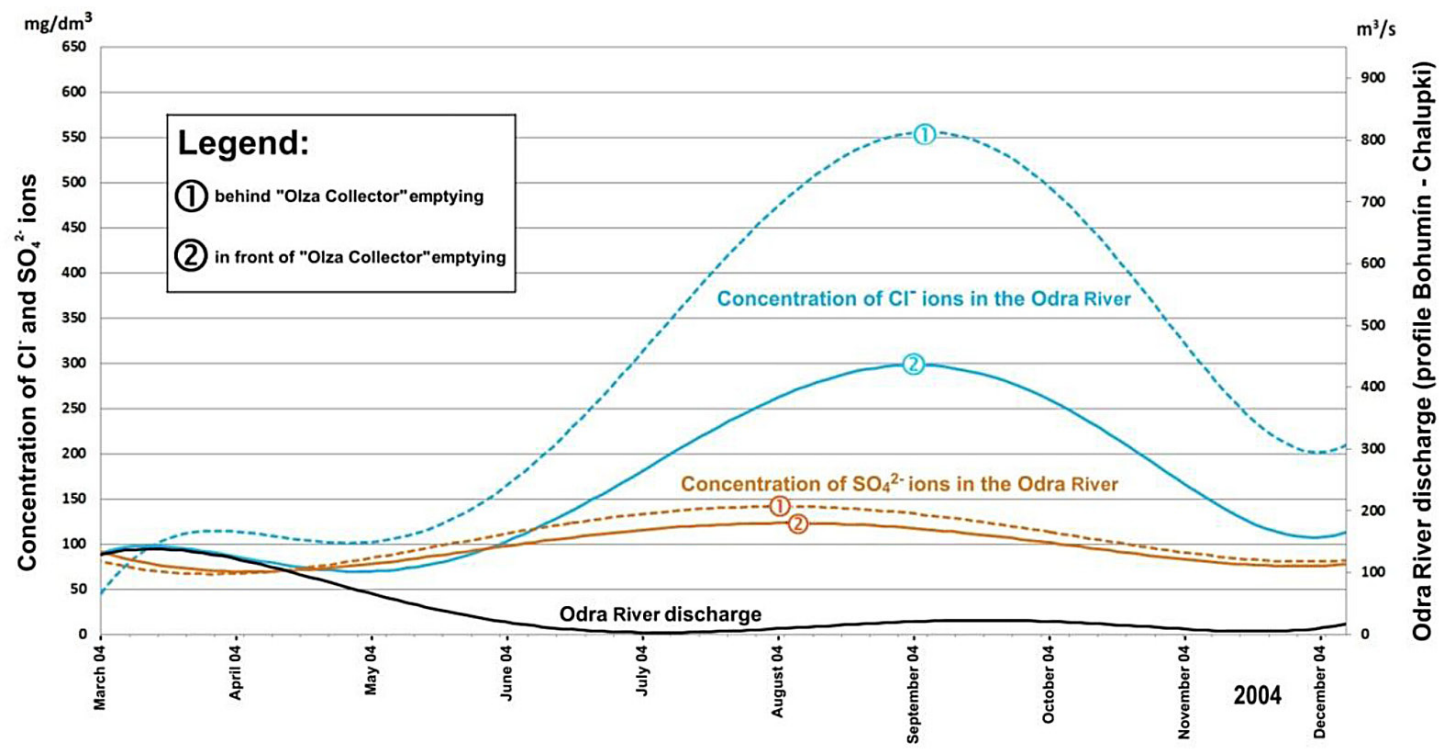

Figure 4. Concentration of $\mathrm{Cl}^{-}$and $\mathrm{SO}_{4}^{2-}$ ions in the Odra River in 2004 [Walaszek 2013]

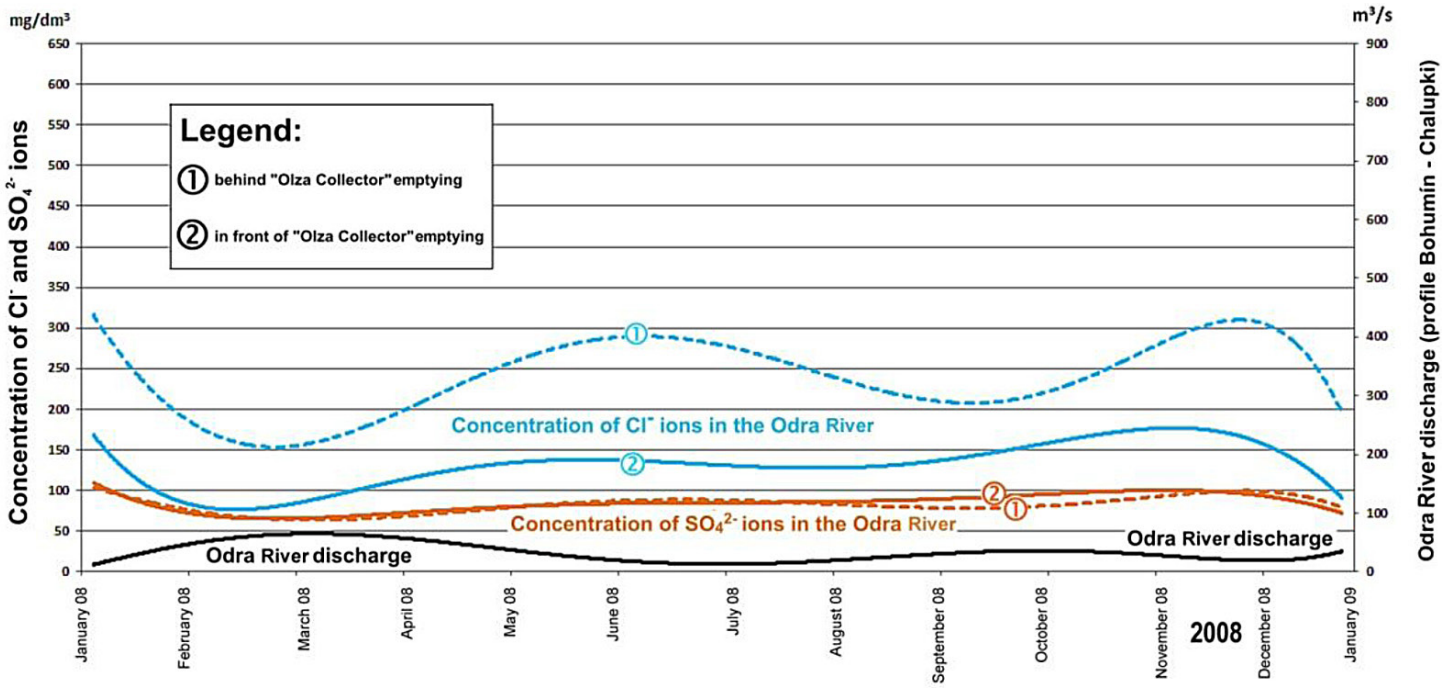

Figure 5. Concentration of $\mathrm{Cl}^{-}$and $\mathrm{SO}_{4}{ }^{2-}$ ions in the Odra River in 2008 [Walaszek 2013] 


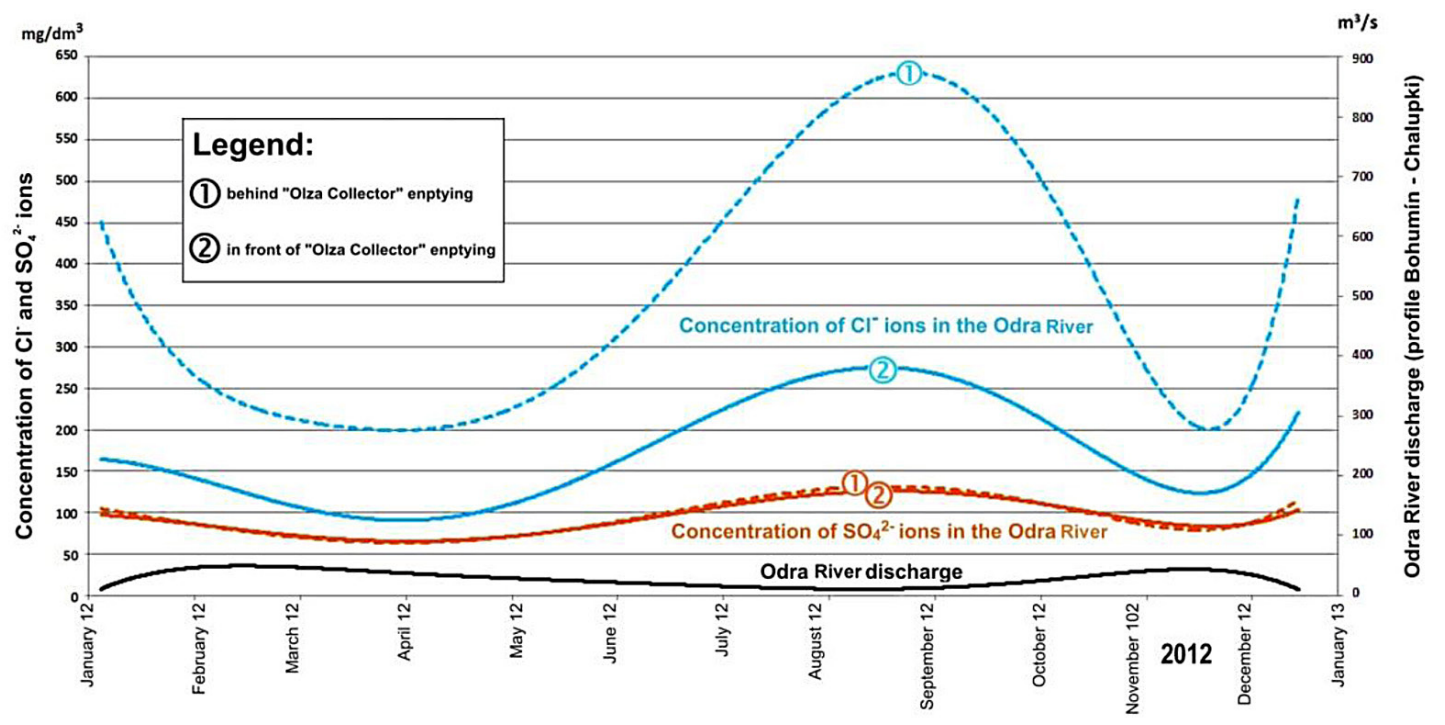

Figure 6. Concentration of $\mathrm{Cl}^{-}$and $\mathrm{SO}_{4}^{2-}$ ions in the Odra River in 2012 [Walaszek 2013]

affected by the discharged mine waters from active and abandoned deep mines. The discharged mine waters are usually mildly to strongly mineralised - generally described as "saline waters". These waters can be, especially in the case of watercourses with low flow rate, the reason of degradation of their original ecosystem. Such watercourse degradation threatened the border Olza River and especially its tributaries in Polish part of the Basin. This is why a technically and economically demanding solution was adopted: discharging of mine (but also waste) waters through an artificial channel - so-called "Olza Collector" - directly to the Odra River, i.e. away of the Olza River and its minor tributaries. Automated control and dosing of waters to the Odra River depending on quality of the discharged waters and quality and quantity of the Odra surface water ensures maintaining of the total content of chlorides and sulphates in Odra below $500 \mathrm{mg} / \mathrm{dm}^{3}$ with the efficiency of more than $90 \%$ of days in a year. This value was defined by internal regulation of the Olza Collector administrator, PGWiR S.A., despite the fact that value of the legally valid TDS limit is more than double. The regulation is driven by the principal of protection of natural sources and quality of surface waters in international watercourses but mainly by the effort to maintain sufficient buffer in quality of the Odra watercourse for discharging of other mine waters in central and northern part of the USCB in Poland.

The "Olza Collector" is an important example of technical solution and practical application of principles of sustainable economy and social development with fully-fledged maintenance of local environment strongly affected by hard coal mining activities.

\section{REFERENCES}

1. Dopita M. et al., 1997. Geologie české části hornoslezské pánve. Ministry of the Environment of Czech Republic, Prague. Monograph, ISBN 807212-011-5.

2. Harat A., Grmela A., 2008. Wpływ wód kopalnianych Górnośląskiego Zagłębia Węglowego na zmiany jakości wody w rzece Olza w latach 20002007. Natural Environment Monitoring, No. 9, Kielce Scientific Society.

3. Lach R. et al., 2003. Operat wodnoprawny na odprowadzanie wód pochodzących z odwadniania kopalń Jastrzębskiej Spółki Węglowej S.A. i kopalń Kompanii Węglowej S.A. kolektorem Olza do rzeki Leśnicy. Central Mining Institute, Katowice.

4. Pluta I., 2005. Wody kopalń Górnośląskiego Zagłębia Węglowego - geneza, zanieczyszczenia i metody oczyszczania. Central Mining Institute, Katowice.

5. Pluta I., Grmela A., 2006. Odprowadzanie wód kopalnianych do Odry w świetle przepisów prawnych w Polsce i Republice czeskiej. $6^{\text {th }}$ Science and Technology Conference Environmental Protection on Mining Areas, AGH-University of Science and Technology Kraków, Central Mining Institute, Katowice.

6. Różkowski A., Pacholewski A., Witkowski A., 2005. Kształtowanie się chemizmu zwykłych wód podziemnych w regionie górnośląskim w warunkach aktywnej antropopresji. Polish Geological Review, 53 (9). 
7. Rusin A., 2007. Reżim jakości wody w rzece Olza od przekroju w Cieszynie do przekroju w Chałupkach w latach 2000-2005. Master's dissertation, University of Bielsko-Biala, Faculty of Materials and Environmental Sciences, manuscript.

8. Schwalbová J., 2009. Vliv těžební činnosti v hornoslezské pánvi na změny kvality řeky Olše v letech 2000-2007. Diploma dissertation, Technical University of Ostrava, Faculty of Mining and Geology, Czech Republic, manuscript.

9. Swolkień J., 2007. Możliwości ograniczenia szkodliwego wpływu wód dołowych na stan rurociągów kolektora „Olza” i środowisko rzeki Odry. Doctoral dissertation, AGH-University of Science and
Technology, Kraków.

10. Walaszek K., 2013. Wpływ kolektora Olza na stan jakości wód rzeki Odra. Master's dissertation, University of Bielsko-Biala, Faculty of Materials and Environmental Sciences, manuscript.

11. Wilk Z. et al., 2003. Hydrologia polskich złóż kopalin i problemy wodne górnictwa, AGH-University of Science and Technology Press, Kraków.

12. Wrześniak A. et al., 2014. Stan środowiska w województwie śląskim w 2013 roku. Regional Inspectorate of Environmental Protection, Environmental Monitoring Library, Katowice (http://www. katowice.pios.gov.pl/monitoring/raporty/2013/raport2013.pdf) 